\title{
İlkokul öğrencilerinin sürekli kaygı, yetkinlik ve üzüntü yönetimine ilişkin araştırma
}

\section{A Research about trait anxiety, self-efficacy, and sadness management of primary school students}

\author{
Tuğba Seda Çolak, Yrd. Doç. Dr., Düzce Üniversitesi, Eğitim Fakültesi, Rehberlik ve Psikolojik \\ DanışmanlıkABD, tugbacolak@duzce.edu.tr \\ Gülperi Eren, Psikolojik Danışman, Milli Eğitim Bakanlı̆̆ı, gulperiatici20@hotmail.com \\ Uğur Doğan, Yrd. Doç. Dr., Muğla Sitkı Koçman Üniversitesi, Eğitim Fakültesi, Rehberlik ve Psikolojik \\ Danışmanlık ABD, ugurdogn@gmail.com
}

\begin{abstract}
ÖZ. Bu araştırmanın amacı, ilkokul düzeyindeki öğrencilerin sürekli kaygı düzeyleri ile yetkinlik düzeyleri ve üzüntü yönetim becerileri arasındaki ilişkinin incelenmesidir. Araştırmanın çalışma grubunu Muğla İli Bodrum İlçesindeki bir İlkokul bünyesindeki 2. 3. ve 4. sınıf öğrencileri 105 kız öğrenci ve 106 erkek öğrenci olmak üzere toplam 211 öğrenci oluşturmaktadır. Araştırmada veriler için Sürekli Kaygı ölçeği (Öner ve Le Compte, 1985; Spielberger, Gorsuch ve Luschene, 1970) , Çocuklar için Öz-Yeterlik Ölçeği (Muris, 2001; Telef ve Karaca, 2012) ve Üzüntü Yönetimi Ölçeği (Akın ve diğ., 2014; Zeman, Shipman ve Penza-Clyve, 2001) kullanılmıştır. Verilerin istatistiksel analizi için Pearson Momentler Çarpımı Korelasyonu, t-testi ve yapısal eşitlik modeli kullanılmıştır. Araştırma sonucunda, üzüntü yönetiminin yetkinliği, yetkinliğin de sürekli kaygıyı anlamlı düzeyde açıkladığı bulunmuştur. Ayrıca üzüntü yönetiminin sürekli kaygıyı anlamlı düzeyde açıklamadığı fakat üzüntü yönetiminin sürekli kaygıyı yetkinlik inancı üzerinden yordadığı belirlenmiştir. Bunun yanı sıra araștırmada kullanılan kavramlar cinsiyet değișkeni açısından değerlendirildiğinde anlamlı bir fark bulunmamıștır. Bulgular alan yazın ıșığında tartışılmıștır. Gelecek çalışmalar ve alan çalışanları için önerilerde bulunulmuștur.
\end{abstract}

Anahtar Kelimeler. Yetkinlik, Üzüntü Yönetimi, Sürekli Kaygı, Yapısal Eşitlik Modellemesi.

\begin{abstract}
The aim of this study was to investigate the relationship between levels of self-efficacy, skills to sadness management, and trait anxiety of primary school students. Study group of the research consists of 211, which consists of 105 female, 106 male, 2nd, 3rd and 4th grade students in a Primary School. Trait Anxiety Scale (Öner \& Le Compte, 1985; Spielberger et al., 1970), Self-Efficacy Scale for Children (Muris, 2001; Telef \& Karaca, 2012) and Sadness Management Scale (Akın et al., 2014; Zeman, Shipman \& Penza-Clyve, 2001) were used to collect data. Data analysis methods are Pearson Product Moment Correlation, t-test and structural equation model. As a result, sadness management explains self-efficacy; self-efficacy explains trait anxiety at significance level. Also, sadness management does not explain trait anxiety at significant level but sadness management predict trait anxiety over self-efficacy. There isn't found any significant difference for gender. The findings are discussed in terms of literature. Suggestions for academicians and field workers are stated in the text.
\end{abstract}

Keywords. Self-Efficacy, Sadness Management, Trait Anxiety, Structural Equational Model

\section{SUMMARY}

Purpose and Significance: The study is aimed to determine the relation between trait anxiety, sadness management and self-efficacy for primary school children. Emotion management is a vital factor for mental health and it is known that basic emotions have been developing since birth. Adults, who children trust them, are very important for gaining emotion management skills. Especially sadness is a negative emotion and can affect the person negatively. Self-efficacy may be described as trust for skills the person has. The concept may be affected by external factors like parents, peers, teachers or any negative experience. Anxiety is an important factor which effects life negatively. All this concepts are important for mental health. There isn't seen any research about emotion regulation of children. Especially sadness is a basic emotion and it can be handled as keystone for future emotion management skills. It is thought that to reveal the relation between these concepts is important for mental health for children. 
Methodology: The data was collected from a Primary School which is located in district of Bodrum in Muğla. 106 male and 105 female pupils have participated the research. Convenience sampling method has been adopted to choose study group. Researchers gave information about tests and process of the study to the pupils. Trait Anxiety Scale, Self-Efficacy Scale and Sadness Management Scale were used to collect data. Pearson Product Moment Correlation, t-test, and structural equation model was used for statistical analysis of data.

Results: Sadness management explains self-efficacy; self-efficacy explains trait anxiety at significance level. It is found that sadness management doesn't explain trait anxiety at significance level. Results show that self-efficacy has a role of mediator between sadness management and trait anxiety. In addition, when the concepts of the research are assessed in terms of gender variable, there isn't found any significant difference.

Discussion and Conclusions: Results show that self-efficacy has a mediator role between sadness management and trait anxiety. If this result is considered in terms of study group's developmental period, it can be used effectively. It can be clearly seen that there isn't any differentiations by the means of gender. Social expectancies may form gender roles. Stigmatization about gender roles can cause some problems about anxiety, self-efficacy, and sadness management. It is thought that gaining of sadness management and self-efficacy can be effective to cope with anxiety and other negative components of life. All the results show that gaining sadness management is an important factor for mental health. For this reason parents should be educated about their role in emotion management skill development period. Especially school counsellors should help pupils to develop self-efficacy belief.

\section{GíRIş}

Kaygı insanoğlunun doğal duygularından bir tanesi olmakla beraber, ilk duyulduğunda olumsuz çağrışımlar yapsa da kontrol edilebildiğinde ve doğru bir şekilde yönetildiğinde kişi için faydalı olan ve olmazsa olmaz duygulardan bir tanesidir. Kaygı genel anlamda başarı öncesi güdülenme ve motivasyon aracı olarak pozitif yönde işleve sahip olurken, kaygı türleri incelendiğinde ayrılık kaygısında görüldüğü gibi negatif etkilerle de kendini göstermektedir. Gelişimin hızlı bir şekilde ilerlediği erken yaşlarda ortaya çıkan bu durum çocuğun zihinsel, duygusal ve sosyal gelişim alanlarına etki etmektedir. Kaygı ile ilgili çeşitli tanımlar ortaya atılmış olup, kaygı türleri konusunda da alanyazında çalışmalar bulunmaktadır.

Dinçmen (2004) kaygıyı kaynağını bilinçten ya da bilinçdışından alan bireyin kendisinden ya da çevresinden kaynaklanan faktörler nedeniyle yaşadığı, bireyde dengesizlik meydana getiren bastırılmış materyalin yeniden bilinç düzeyine çıkma çabasından kaynaklanan huzursuzluk olarak tanımlamıştır. Bunaltı ya da sıkıntı kelimelerine karşılık gelen kaygı, bireyde rahatsızlık meydana getiren herhangi bir olay ya da durumun ortaya çıkardığı yaygın bir tepkidir (Alper, Bayraktar ve Karaçam, 2001). Bunun yanı sıra kaygının, nevrozun merkezi olduğuna dair tanımlamalar mevcuttur (Horney, 1998; McKenzie, 2006) ve "nevrotik anksiyete"de rastlandığı gibi mantıkdışı bir forma büründügünde, bireyde uyum ve davranış problemleri meydana getirdiği (Geçtan, 1995) ifade edilir.

Kaygı tanımlanmak istendiğinde, durumluk kaygı ve sürekli kaygı olmak üzere iki formda tanımlanmıștır. Durumluk kaygı stres faktörlerine maruz kalınan ortamlarda bireylerin bedensel tepkilerinin de eşlik ettiği, huzursuzluk hali yaşama ve bu ortam ya da durumların ortadan kalkmasıyla huzursuzluğun azalması olarak tanımlanırken; sürekli kaygı bireyin yaşadığı duruma direkt bağlı olarak yorumlanamayan, bireyin kaygı yaşama durumuna yatkınlığını ifade eden bir kişilik özelliği olarak tanımlanır (Öner ve LeCompte, 1985). Durumluk kaygı geçici bir tehlike ya da stres durumunu içerirken, sürekli kaygı nötr durumlarda dahi bir tehlike hissetme eğilimini ifade eder ve yüksek düzeyde görüldüğünde bireyin yaşamla uyumunu bozan bir unsurdur. Araştırma sonuçları kaygı ve yetkinliğin birbiriyle negatif ilişkili kavramlar olduğunu ortaya koymuştur (Muris, 2002; Tahmassian ve Moghadam, 2011; Yerdelen, McCaffrey ve Klassen, 2016). 
Özyeterlilik/yetkinlik kavramı, kişinin kendi motivasyonu ve davranışları üzerinde kontrol sahibi olabileceğine ilişkin inancını içerir. İnsanların yetenekleri hakkındaki inançları, yapmayı tercih edecekleri şeyler konusunda kararlarını belirler. Birey yetkinlik inancından yoksun olduğunda, gerekli yeteneklere sahip olsa bile durumu etkili yönetemez (Bandura, 1990). Yetkinlik inancl, gerçek performans, dolaylı deneyim, sözlü ikna ve fizyolojik tepkiler olmak üzere dört kaynaktan kazanılır ve dişsal faktörlerden çabuk etkilenen bir kavramdır (Schunk ve Meece, 2006). Bireyin yetkinlik inancı, performansının başarılı olma düzeyinin ne oranda olacağını öngörmesine yardım eder (Çetin, 2013; Plotnik, 2009). Bandura (1998), birey için korkutucu olan durumları yönetemeyeceğine ilişkin olan inancının, yüksek düzeyde kaygıyla uyarılmasına neden olacağını belirtir. Bireyin potansiyel tehlike arz eden durumlar üzerinde kontrol sahibi olmasını sağlayan yetkinlik inancı düzeyi kaygının uyarılmasında merkezi rol oynar.

Benlik, bilişler, anılar, duygular karşılıklı olarak birbirini belirleyen unsurlardır (Sarp ve Tosun, 2011). İnsan çok boyutlu bir varlık olduğundan tüm bu unsurlar bir etkileşim halinde oluşur. Ebeveyn çocuk ilişkilerinde yaşanan aksaklıklar çocuğun duygusal ve sosyal yaşamı baz alındığında kalıcı etkiler bıraktığı görülebilir. $\mathrm{Bu}$ durum kaygı duygusunun zeminini hazırlamaktadır (Alisinanoğlu ve Ulutaș, 2000; Geçtan, 1995). Kaygı klasik koşullanma, gözlem yoluyla öğrenme ve bilinçdışında meydana gelen çatışma yollarıyla gelişir (Plotnik, 2009) ve annelerin sahip olduğu kaygı düzeyi çocukluk döneminde ortaya çıkan kaygı ile doğrudan ilişkilidir (Alisinanoğlu ve Ulutaş, 2003).

Anne-babanın çocuklara karşı gösterdiği kabul veya reddedici davranışlar, çocukların psikolojik ve duygusal gelişimleriyle yakından ilişkilidir (Önder ve Gülay, 2007). Kaygılı çocukların anneleri, çocuklarının negatif duygularına karşılık verirken daha az destekleyici tutum sergilemektedir (Hurrell, Hudson ve Schniering, 2015). Duyguların ifade edilmesine karşı destekleyici olmayan ebeveyn tepkileri, çocukların duygu düzensizlikleri yaşamalarına ve daha zayıf duyguyla başa çıkabilme becerisi göstermelerine neden olmaktadır (Sanders, Zeman ve Poon, 2015). Bunun yanında annenin empatik becerileri ve destekleyici tutumunun, çocuğun kendi duygularını anlamasına olanak sağladığı (Güngör-Aytar ve Kurbet-Dinçer, 2014); çocukların üzüntülerine karşı verilen olumlu tepkilerin üzüntü yönetimi üzerinde eşsiz etkileri olduğu (Tillery, Cohen, Parra, Kitzmann ve Howard-Sharp, 2015) saptanmıştır.

Utanç, suçluluk, kıskançlık, umut gibi duygular çocukluk ve ilkokul yaşlarında oluşmaya başlarken öfke, korku, üzüntü, neşe ve sevgi duyguları yaşamın ilk yıllarından gelişmeye başlar (Holodynski ve Friedlmeier, 2006) ve doğumdan sonraki 10-12 aydan itibaren bağlanma figürü olan yetişkinle olan ilişkiler duygu düzenlemesinin merkezini oluşturur (Sroufe, 2000). Temel duygulardan olan üzüntü bireyin yaşamından doyum almasını olumsuz etkiler ve rahatsız edici bir duygudur. Çocuklarda üzüntü yönetimi ihmal edilen bir konu olmasının yanında depresyon, çocuklukta görünen yas gibi problemlerle doğrudan bağlantıdır (Zeman ve diğ., 2001). Duygu yönetimi ruh sağlı̆̆ı için önemli bir kavramken Türkiye'de alanyazın tarandığında konunun daha çok çalışma hayatı ve örgütsel bağlamda ele alındığı (Akçay ve Çoruk, 2012; Korkmaz, 2005; Töremen ve Çankaya, 2008) ve çoğunlukla öfke yönetimi (Cenkseven, 2003; Karataş, 2009; Soykan, 2003), stres yönetimi (Akova ve Işık, 2008; Birkök, 2004; Güçlü, 2001) gibi toplumsal yaşama negatif etkisi olan duygular üzerinde çalışıldığı görülmektedir. Genellikle yetişkin ve ergen grupları üzerinde yapılan araştırmalar mevcut olmasına rağmen, çocukların duygu yönetimine ilişkin araştırmalar azınlıktadır. Çocukluk döneminde, temel duygulardan üzüntünün (Johnson-Iaird ve Oatley, 1989) yönetimi becerisi kazanmanın, yaşamdaki olumsuz faktörleri azaltmada önemli bir etken olacağı düşünülmektedir.

Kaygı, yetkinliğin düşük algılanması ve duygu yönetiminde yaşanan problemler çocukluk döneminde gözlenen ve birbiriyle ilişkili olduğu düşünülen sorunlar arasındadır. Araştırma kapsamında ilkokul 2., 3. ve 4. Sınıf öğrencilerinden seçilen örneklemden elde edilen verilerle sürekli kaygı, yetkinlik ve üzüntü yönetimi kavramlarının ilişkisini araştırmak amaçlanmıştır. 


\section{YÖNTEM}

\section{Çalışma Grubu}

Çalışma Muğla İline bağlı Bodrum İlçesindeki bir ilkokulda öğrenim hayatlarına devam eden 211 ilkokul öğrencisinin katılımlarıyla gerçekleştirilmiştir. Çalışma grubunu oluşturan öğrenciler okulların 2. (\%30), 3. (\%34), 4. (\%36) sınıflarına devam eden, yaşları 7 ile 11 arası değișen ve yaş ortalaması 9.3 olan, 106'sı erkek (\%50.2), 105'i kız (\%49.8) öğrencilerdir. Çalışma grubunun seçiminde seçkisiz olmayan, uygun örnekleme yöntemi benimsenmiştir.

\section{Veri Toplama Aracı}

Çocuklar için Yetkinlik Ölçeği: Ölçeğin orijinali Muris (2001) tarafından geliştirilmiş, Türkçeye uyarlaması Telef ve Karaca (2012) tarafından yapılmıştır. 21 maddeli "hiç" ile "çok iyi" ve 1-5 arasında değișen derecelendirme ölçeğidir. Ölçek, genel yetkinlik, sosyal yetkinlik ve akademik yetkinlik isimli üç alt boyuttan oluşmaktadır. Ölçeğin yapılan geçerlik çalışmalarında toplam varyansın \%43.74'ünü açıklayan, faktör yük değerleri .39 ile .77 arasında değişen, orijinali ile aynı değerler verdiği görülen bir yapı elde edilmiștir. Ayrıca yapılan doğrulayıcı faktör analizinde iyi uyum indeksleri verdiği görülmüştür $\left(\chi^{2}=614.68\right.$, GFI=.94, CFI=.96, RMSEA=.050). Ölçeğin güvenirlik değerlerini belirlemek için Cronbach alfa değerlerine bakılmış, ölçeğin bütünü için .86 alt boyutlar için ise sosyal yetkinlik için .64, duygusal yetkinlik için .78, akademik yetkinlik için .84 Cronbach alfa değerleri elde edilmiştir. Bu çalışma için yapılan doğrulayıcı faktör analizi çalışmasında ise iyi uyum indekslerine ulaşılmış ve sonuçlar tablo 3'de verilmiştir, Cronbach Alpha değeri .83 bulunmuştur.

Üzüntü Yönetimi Ölçeği: Orijinal formu Zeman ve diğ. (2001) tarafından geliștirilen, Akın ve diğ. (2014) tarafından Türkçeye uyarlaması yapılmış olan ölçek 12 madde ve düzensiz dışa yansitma ( 3 madde), duygusal düzenleme (5 madde) ve engelleme (4 madde) olmak üzere 3 alt boyuttan oluşmaktadır. Ölçeğin Türkçe uyarlama çalışması için doğrulayıcı faktör analizi yapılmış, faktör yüklerinin .27 ile .68 arasında sıralandığı ve iyi uyum indeksleri verdiği görülmüştür $\left(x^{2}=86.49, \mathrm{sd}=51, \mathrm{RMSEA}=.059, \mathrm{CFI}=.80, \mathrm{IFI}=.82, \mathrm{GFI}=.93, \mathrm{AGFI}=.90, \mathrm{SRMR}=.073\right)$. Bu çalışma için yapılan doğrulayıcı faktör analizi çalışmasında ise iyi uyum indekslerine ulaşılmış ve sonuçlar tablo 3'de verilmiştir, Cronbach Alpha değeri .61 bulunmuştur.

Sürekli Kaygı Ölçeği: Orijinal formu Spielberger ve diğ. (1970) tarafından durumluk ve sürekli kaygı seviyelerini ayrı ayrı saptamak amacıyla geliştirilen ölçeğin Türkçeye uyarlanması, güvenirlik ve geçerlik çalışmaları Öner ve Le Compte (1985) tarafından yapılmıştır. Öz değerlendirme türü bir ölçektir. Toplam 40 maddeye sahip iki ayrı ölçekten oluşmaktadır. Bu çalışmada envanterin 20 maddelik "Sürekli Kaygı Ölçeği" kullanılmıştır. Çocuğun genellikle nasıl hissettiğini oluş sıklığına göre değerlendirir. "Evde sinirlerim bozulur" ya da "Ellerim titrer" gibi ifadeler, "hemen hemen hiç", "bazen" ve "sık sık" seçeneklerinden biriyle yanıtlanır. Ölçekten alınacak puanlar 20-60 arasındadır, puanların artışı sürekli kaygıdaki artışı ifade etmektedir. Yapılan doğrulayıcı faktör analizi çalışmasında iyi uyum indekslerine ulaşılmış ve sonuçlar tablo 3'de verilmiştir, Cronbach Alpha değeri .85 bulunmuştur.

\section{Verilerin Analizi}

Araştırmanın uygulama aşaması için 2, 3 ve 4. sınıflara girilerek katılımcılara ölçeğin yapılış şekli, kodlama şekilleri, ölçeğin hangi amaçla yapıldığı gibi açıklamalarla birlikte, katılımcılar tarafından anlaşılmakta zorlanılan maddelerde açıklamalar yapılmıştır (özellikle 2. sınıflarda). Verilecek cevapların gizliliği konusunda ve not değeri taşımadı̆̆ı yönünde açıklamalar yapılmıştır. Öz yetkinlik, üzüntü yönetimi ve sürekli kaygı arasındaki ilişkiyi belirlemek için Pearson korelasyon tekniği, bağımsız değişkenin bağımlı değişkeni yordama düzeyine bakmak için de yapısal eşitlik modeli (YEM) kullanılmıştır. Bunun dışında cinsiyetin anlamlı birer yordayıcı olup olmadığını belirlemek amacıyla da Independent Sample t-Testi yapılmıștır. 


\section{BULGULAR}

\section{Betimsel İstatistikler}

Araştırmanın bu bölümünde çalışma grubuna ait betimsel istatistikler ve $t$ testi sonuçları verilmiştir. Tablo 1'de Yetkinlik, Üzüntü Yönetimi ve Sürekli Kaygı arasındaki ilişkilere yönelik betimsel istatistikler ve korelasyonlar verilmiştir.

Tablo 1.Yetkinlik, Üzüntü Yönetimi ve Sürekli Kaygı Arasındaki İlişkilere Yönelik Korelasyon Katsayıları ve Betimsel İstatistikler

\begin{tabular}{lllllc}
\hline Değişkenler & Ort & SS & $\mathbf{1}$ & $\mathbf{2}$ & $\mathbf{3}$ \\
\hline 1-Yetkinlik & 83.203 & 7.3 & 1 & & \\
2-Üzüntü Yönetim & 25.706 & 12.1 & $.289^{* *}$ & 1 & \\
3-Sürekli Kaygı & 35.502 & 3.9 & $-.290^{* *}$ & -.088 & 1 \\
\hline
\end{tabular}

${ }^{* *} \mathrm{p}<.01, \mathrm{n}=211$

Tablo 1'de modeldeki değişkenlere ait korelasyonlar sunulmuştur. Görüldüğü gibi yetkinlik ve üzüntü yönetimi arasında ( $\mathrm{r}=.289^{* *}$ ) pozitif ve anlamlı düzeyde bir ilişki olduğu, sürekli kaygı ve yetkinlik arasında ( $\left.r=-.290^{* *}\right)$ ters yönde anlamlı bir ilişki olduğu ve üzüntü yönetimi ve sürekli kaygı arasında(r=-.088) ters yönde ve anlamsız bir ilişki olduğu sonucu elde edilmiştir.

Araştırmanın betimsel istatistiklerinin yanında araştırma grubuna katılan öğrencilerden elde edilen puanlarda cinsiyete göre farklılık olup olmadığı test edilmiştir. Yapılan t testine ilişkin analiz sonuçları tablo 2'de verilmiştir.

Tablo 2. Sürekli Kaygı, Üzüntü Yönetim ve Yetkinlik Ölçeği Puanlarının Cinsiyete Göre t-Testi Sonuçları

\begin{tabular}{|c|c|c|c|c|c|c|}
\hline Değişkenler & Cinsiyet & $\mathrm{n}$ & Ort & SS & $\mathrm{t}$ & $p$ \\
\hline \multirow{2}{*}{ Yetkinlik } & $\mathrm{K} 1 \mathrm{z}$ & 105 & 84.10 & 7.5 & \multirow{2}{*}{1.076} & \multirow{2}{*}{.283} \\
\hline & Erkek & 106 & 82.30 & 7.2 & & \\
\hline \multirow{2}{*}{ Üzüntü Yönetim } & $\mathrm{Kiz}$ & 105 & 25.32 & 12.5 & \multirow{2}{*}{-1.393} & \multirow{2}{*}{.165} \\
\hline & Erkek & 106 & 26.08 & 11.7 & & \\
\hline \multirow{2}{*}{ Sürekli Kaygı } & $\mathrm{Kiz}$ & 105 & 35.45 & 3.8 & \multirow{2}{*}{-.088} & \multirow{2}{*}{.930} \\
\hline & Erkek & 106 & 35.54 & 4.1 & & \\
\hline
\end{tabular}

Tabloya bakıldığında, araştırma grubunun yetkinlik, üzüntü yönetimi ve sürekli kaygı puanlarının cinsiyete göre anlamlı bir farklılık göstermediği görülmektedir ( $\mathrm{t}=-.088$, $\mathrm{p}>.01)$. Bir diğer ifade ile ele alınan üç değişkenin cinsiyete göre farklılaşmadığı görülmüştür.

\section{Yapısal Eşitlik Modeli (YEM)}

Diğer yandan yapılan analizlere ek olarak yetkinlik inancı ve üzüntü yönetiminin araştırmanın bağımlı değişkeni olan sürekli kaygıyı yordamasına ilişkin YEM yapılmıştır. YEM, iki veya daha fazla değişken arasındaki ilişkiyi incelemek için kullanılmaktadır. Yetkinlik, üzüntü yönetimi ve sürekli kaygı arasındaki ilişki örüntüsünü tespit etmek için AMOS 20 (Arbuckle, 2011) kullanılmıştır. Analize başlamadan önce değişkenlere ait ölçüm modelleri hesaplanmış ve analizlere ilişkin iyilik değerleri Tablo 3'de verilmiștir.

Tablo 3.Yetkinlik, Üzüntü Yönetimi ve Sürekli Kaygı Ölçüm Modellerine İlişskin İyilik Değerleri

\begin{tabular}{lcccccccc}
\hline Değişkenler & $\boldsymbol{X}^{\mathbf{2}}$ & $\mathbf{d f}$ & $\boldsymbol{X}^{\mathbf{2}} / \boldsymbol{d} \boldsymbol{f}$ & RMSEA & SRMR & CFI & NNFI & IFI \\
\hline Yetkinlik & 263.30 & 189 & 1.39 & .043 & .57 & .96 & .96 & .96 \\
Üzüntü Yön. & 136.35 & 52 & 2.61 & .088 & .42 & .92 & .95 & .93 \\
Sürekli Kaygl & 235.93 & 170 & 1.38 & .043 & .56 & .96 & .96 & .96 \\
\hline
\end{tabular}

Not: $x 2$ = Ki-kare; $d f=$ Serbestlik Derecesi, RMSEA =Yaklaşık hataların ortalama karekökü; SRMR = Standartlaştırılmış hata kareleri ortalamasının karekökü; CFI = Karşılaştırılmalı uyum indeksi; NNFI = Normlaştırllmamış uyum indeksi; IFI = Artırmalı uyum indeksi 
Bütün ölçüm modellerinin kabul edilebilir uyum indeksleri verdiği görülmüştür. Ölçüm modelleri belirlendikten sonra, YEM AMOS 20 (Arbuckle, 2011) ile gerçekleştirilmiştir. Modele ilişkin veriler şekil 1'de verilmiştir.

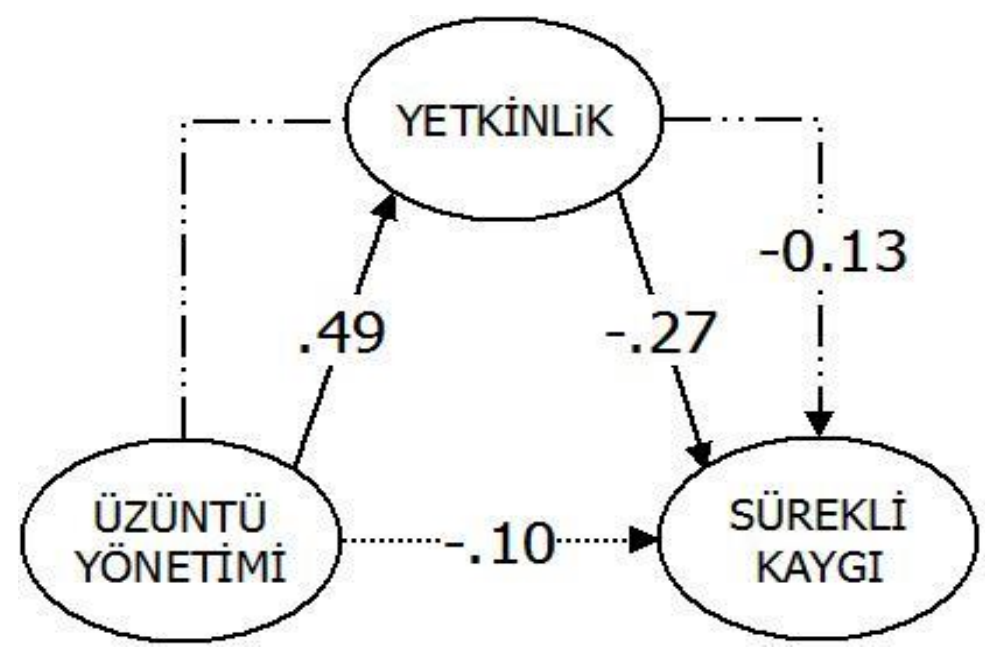

Şekil 1.Yetkinlik, Üzüntü Yönetimi ve Sürekli Kaygı'ya ilişkin YEM

Şekil 1'de görüldüğü gibi üzüntü yönetiminin yetkinliği pozitif, yetkinliğin sürekli kaygıyı negatif ve anlamlı olarak yordadığı ancak üzüntü yönetiminin sürekli kaygıyı doğrudan yordamadığı ortaya konmuştur. Bulgulara ek olarak üzüntü yönetimi ile sürekli kaygı arasında doğrudan bir ilişki olmamasına rağmen dolaylı bir ilișki olduğu ve üzüntü yönetiminin sürekli kaygıyı dolaylı olarak etkilediği bulunmuștur. Bu ilișkiye yetkinliğin aracılık ettiği görülmektedir. YEM için uyum indeksleri incelendiğinde iyi uyum indekslerine sahip olduğu görülmüştür $\left(X^{2}: 1799\right.$, sd:1323, $X^{2} / s d: 1.36$, RMSEA: .067, RMR: .90, GFI: .89, NFI: .092). Analize ilişkin tahmin değerleri tablo 4'de verilmiştir.

Tablo 4. Üzüntü Yönetimi, Yetkinlik ve Yetkinliğe İlişkin Tahmin Değerleri

\begin{tabular}{|c|c|c|c|c|c|c|c|c|}
\hline Yordanan & & Yordayan & $\begin{array}{l}\text { Standardize } \\
\text { edilmemiş } \\
\text { tahmin } \\
\text { değerleri } \\
\text { (B) }\end{array}$ & S.E. & $\begin{array}{c}\text { C.R. } \\
\text { (t- } \\
\text { değeri) }\end{array}$ & $\begin{array}{c}\text { Standardize } \\
\text { edilmiş } \\
\text { tahmin } \\
\text { değerleri } \\
(\beta)\end{array}$ & $\mathbf{R}^{2}$ & $p$ \\
\hline Yetkinlik & $\leftarrow$ & $\begin{array}{l}\text { Üzüntü } \\
\text { Yönetimi }\end{array}$ & 2.189 & 1.175 & 1.997 & .488 & .24 & .04 \\
\hline Sürekli Kaygı & $\leftarrow$ & Yetkinlik & -.111 & .045 & -2.439 & -.274 & .11 & .04 \\
\hline Sürekli Kaygı & $\leftarrow$ & $\begin{array}{c}\text { Üzüntü } \\
\text { Yönetimi }\end{array}$ & -.190 & .219 & -.866 & -.104 & --- & .35 \\
\hline
\end{tabular}

Değişkenler arasındaki ilişkinin anlamlılık düzeyi incelendiğinde üzüntü yönetiminin yetkinliği pozitif ve anlamlı olarak yordadığı $(\beta=-.488$; $p<.05)$, yetkinliğin sürekli kaygıyı negatif ve anlamlı olarak yordadığı $(\beta=-.274 ; p<.05)$ görülürken üzüntü yönetimi ile sürekli kaygı arasında doğrudan bir ilişki olmadığı ( $\beta=-.104 ; p>.05)$ görülmektedir.

Araştırmada ele alınan değişkenler açısından dolaylı etkilere yönelik bulgular tablo 5'de verilmiştir.

Tablo 5. Üzüntü Yönetimi, Yetkinlik ve Sürekli Kaygı Arasındaki Dolaylı Etkiler

\begin{tabular}{lccc}
\hline & $\begin{array}{c}\text { Üzüntü } \\
\text { Yönetimi }\end{array}$ & Yetkinlik & $\begin{array}{c}\text { Sürekli } \\
\text { Kaygl }\end{array}$ \\
\hline Yetkinlik & .000 & .000 & .000 \\
Sürekli Kaygl & $-.134^{*}$ & .000 & .000 \\
\hline
\end{tabular}

$* \mathrm{P}<.05$ 
Tablo 5'de görüldüğü gibi araştırmada ele alınan değişkenler arasında sadece sürekli kaygı ile üzüntü yönetimi arasında dolaylı bir etkinin olduğu görülmektedir. Üzüntü yönetiminin, yetkinlik üzerinden sürekli kaygıyı yordadığı bulunmuştur $(\beta=-.134 ; \mathrm{p}<.05)$.

\section{TARTIŞMA ve SONUÇ}

Araştırma sonucunda üzüntü yönetimi ve sürekli kaygı arasındaki ilişkiyi sağlayan aracı değişkenin yetkinlik olduğu bulunmuştur. Bunun yanında üzüntü yönetimi, sürekli kaygıyı doğrudan yordamamaktadır. Araştırmada elde edilen bir diğer sonuç ise üzüntü yönetimi, sürekli kaygı ve yetkinlik puanları değerlendirildiğinde cinsiyet değişkenine göre anlamlı bir fark bulunmamıștır. Türkiye'de duygular üzerinde yapılan çalışmaların genelde yetişkin veya ergen gruplar üzerinde ve toplumsal yaşamda dikkat çeken öfke, stres gibi duygulara odaklandıkları görülmektedir. Duygu oluşumunun doğumdan itibaren başlayan bir unsur olduğu düşünüldüğünde, erken yaşlarda duygu düzenleme becerilerinin edinilmesinin hem bireyin ruh sağlığına olumlu etkileri olacağı, hem de toplumsal yaşamda önleyici bir görev göreceği düşünülmektedir. Bu anlamda araştırma sonuçları önem arz etmektedir.

Bulgular üzüntü yönetimi ve sürekli kaygı arasında doğrudan bir ilişki olmadığını göstermektedir. İlgili alanyazın tarandığında kaygı ve üzüntü yönetiminin doğrudan ilişkili olduğunu gösteren bulgulara rastlanmaktadır. Zeman, Shipman ve Suveg (2002) duygu durumunu tanımlamada yetersizlik, öfke ve üzüntünün düzenlenememesi gibi durumların durumluk-sürekli kaygı ve depresyonla açıklandığı sonucuna ulaşmıștır. Aynı zamanda Suveg ve Zeman (2004) 8-12 yaş aralığında DSM-IV kaygı bozukluğu tanı kriterlerini karşılayan çocukların endişe, üzüntü ve öfke deneyimlerini yönetmekte zorluk yaşadıklarını tespit etmiştir. Mevcut araştırmada elde edilen sonuç üzüntü yönetimi ve sürekli kaygı arasındaki ilişkiyi sağlayan aracı değișkenin yetkinlik olduğunu ortaya koyması açısından önemlidir.

Araştırma bulgularına göre yetkinlik, sürekli kaygı ve üzüntü yönetimi arasındaki ilișkiyi sağlayan aracı değişkendir. Bunun anlamı üzüntü yönetimi yetkinliği etkilerken, yetkinlik de sürekli kaygıyı etkilemektedir. Bu bulgudan hareketle üzüntüsünü yönetebilen çocuğun kendisini daha yeterli gördügü ve kaygılarını kontrol etmekte de daha başarılı olduğu söylenebilir. Böylece üzüntünün olumsuz etkisinin ortadan kaldırılması, yetkinliğin olumlu etkisini artırırken sürekli kaygıyı da azaltmaktadır. İlgili alanyazında doğrudan ilişkili olmasa da, benzer konularda çalışmalar mevcuttur. Okul öncesi örnekleminde gerçekleştirilen bir araştırma, duygu düzenleme düzeyindeki artışın saldırganlık davranışlarında azalma ve olumlu sosyal davranışlarda artma ile ilişkili olduğunu göstermiştir (Arı ve Yaban, 2016). 60-72 ay arasındaki çocuklarla yapılan bir çalışma duygu düzenleme becerileriyle oyun becerileri arasında pozitif ilișki olduğunu ortaya koymuştur (Koçyiğit, Sezer ve Yllmaz, 2015). Çetinkaya ve Alparslan (2011), üniversite örnekleminde yürüttükleri bir çalışmada duygusal zekanın bir alt boyutu olan duygu düzenleme ve iletişim becerisi arasında pozitif yönde anlamlı bir ilişki olduğunu ortaya koymuştur. Benzer şekilde duygu düzenlemenin üniversite örnekleminde öznel iyi oluşun önemli bir yordayıcısı olduğu bulunmuştur (Özbay, Palancı, Kandemir ve Çakır, 2012). Alanyazında yer alan bulgular da dikkate alındığında, mevcut araştırma ile elde edilen üzüntü yönetiminin yetkinlik üzerinden sürekli kaygıyı yordadığı bulgusu desteklenmektedir.

Araştırma sonucunda yetkinlik ve üzüntü yönetimi arasında pozitif ve anlamlı düzeyde bir ilişki olduğu bulunmuştur. Bir başka ifadeyle bireyin yetkinlik düzeyi arttıkça, üzüntü yönetimi becerisi de artmaktadır. Benzer bir sonuç Özbay ve diğ. (2012)'nın çalışmalarında da ortaya konmuştur. Barutçugil (2004), duygu yönetimini bireyin karar alma sürecinde duygusal beklentilerden arınarak, duygularını çevresindekilere zarar vermeden yönlendirebilmek olarak tanımlamaktadır. Bu tanımdan da yola çıkarak duyguları üzerinde kontrol sağlayabilen bir bireyin, duygusal boşalımı uygun yollarla sağlamayı başardığı söylenebilir. Yetkinlik gibi çevresel faktörlere karşı hassas olan (Schunk ve Meece, 2006) bir özelliğin kazanımı, çocuğun yaşantısında önemli rol oynayan yetişkinlerin, üzücü durumlar karşısında çocukların duygularını yönetebilmeleri konusunda rehber olmaları ile sağlanabilir. Toplumsal anlamda üzücü durumlarda duyguları ifade etmemek ya da duyguların görmezden gelinmesi sık rastlanan bir durumdur. Araştırmalar annelerin üzüntüye karşı verdikleri destekleyici olmayan tepkilerin, çocuklarda depresif belirtilerin artmasına 
neden olduğu (Sanders ve diğ., 2015; Tillery ve diğ., 2015), özellikle ihmal edilmiş ya da kötü muamelelerle yetiştirilmiş çocuklarda duyguları anlama ve düzenleme becerilerinin normal kazanımının sağlanamadığı (Shipman, Edwards, Brown, Swisher ve Jennings, 2005; Shipman ve Zeman, 2001) sonuçlarını ortaya koymuştur. Gelişim sürecinde olumsuz muamelelere maruz kalma ve yetişkinlerin duyguların ifade edilmesine karşı gösterdikleri olumsuz tutumun, çocuğun duygularını tanımlayamamasına ve olumsuz duygulara meyilli olmasına neden olduğu görülmektedir. Araştırmadan elde edilen bulgudan yola çıkarak çevresel faktörlerle yakından ilişkili olan yetkinlik inancının gelişiminin, bireyin kendi duyguları üzerinde kontrol sağlayabilmesiyle desteklenebileceği söylenebilir. Aynı şekilde üzüntü gibi olumsuz bir duyguyu yönetebilme becerisinin bireyin yeteneklerine olan inancı artırması beklenebilir.

Sürekli kaygı ve yetkinlik arasında ters yönde anlamlı bir ilişki olduğu bulunmuştur. Bu sonuç, bireyin yetkinlik düzeyi arttıkça kaygı yaşamaya ilişkin eğiliminin azaldığını göstermektedir. Mevcut araștırma örneklemiyle benzer yaş gruplarını konu alan özyeterlilik ve ilk okuma-yazma başarısı ile ilgili alanyazının incelendiği bir araştırmada öğrencilerin kendilerine ve yeteneklerine olan güveninin öğrencinin çalışma konusunda daha istekli ve ısrarcı olmasını sağladığı bulunmuştur (Akar, 2008). Sürekli kaygı durumunda birey kaygllanmaya neden olacak herhangi bir unsur olmadan da kaygı eğilimi taşır. Yetkinlik bireyin yaşadığı durumlar karşısında kendi sahip olduğu yönlendirme ve yönetebilme becerisine atıfta bulunur. Bireyin, yaşadığı durum içinde güvendiği kaynak kendisidir. Yeteneklerine güvenen birey belirsizlik duygusundan uzaklaşarak kendisini çalışmaya daha kolay adapte edeceği düşünülmektedir. Yetkinlik inancı ile akademik başarı arasında pozitif ilişki bulan araştırmalar (Çetin, 2013) bu yargıyı desteklemektedir.

İlkokul öğrencilerinde üzüntü yönetimi, demografik değişkenler ışığında değerlendirildiğinde cinsiyet ve yaş gibi değișkenlere göre, sürekli kaygı ve yetkinlik arasında herhangi bir fark bulunmamıştır. Alanyazında bu bulguyu destekler nitelikteki çalışmalar (ör. Aral ve Başar, 1998; Arı ve Yaban, 2016) mevcuttur. Gelişim psikolojisi açısından önemli olan bir dönemdeki öğrencilerden elde edilen bu bulgu büyük önem taşımaktadır. İlkokul yaş grubunda henüz cinsiyet rollerine bağlı toplumsal beklentilerin oluşturduğu farklılıkların ortaya çıkmadığı gözlenmektedir. $\mathrm{Bu}$ noktadan hareketle çocukların toplumsal rollerin dayattığı etiketlemelerden uzak, sağlıklı birer birey olması için eğitim faaliyetlerinin düzenlenmesinde bu bilgi anahtar işlev görebilir. "Erkekler ağlamaz", "kadınlar duygusaldır ve korunmaya ihtiyaç duyarlar" benzeri toplumda benimsenmiş olan, ancak yetkinlik inançlarının gelişmesinde ve duygu yönetiminin kazanılmasında olumsuz etkileri olan anlayışlar düzeltilerek doğru kazanımların sağlanması gerçekleştirilebilir. öneriler:

Araştırmadan elde edilen bulgular ıșığında alan çalışanlarına ve gelecek araștırmalara

1. Araştırmadan elde edilen bulgular ışığında küçük yaşlardan itibaren kazandırılacak duygu yönetimi becerileri ile yetkinlik inancının yükseltilmesi ve bu doğrultuda yaşamı olumsuz etkileyen sürekli kaygının da kontrol altına alınması sağlanabilir. Bu bağlamda öğretmen ve ebeveynlerin bilinçlendirilmesi sağlanmalıdır.

2. Duygu yönetimi kavramının bireyin yaşantısında önemli bir yere sahip olduğu düşünüldüğünden, bireylerin yaşamlarına yön verme konusunda etkili olan temel duyguların yönetimine ilişkin deneysel çalışmalar yapılabilir.

3. Aynı örneklem grubu üzerinde ölçümler boylamsal bir şekilde tekrarlanarak değişkenlerdeki değişimler tespit edilerek demografik özelliklere göre farklılaşma görülen kritik dönemler saptanabilir.

4. Okul psikolojik danışmanlarınca okullarda küçük yaş gruplarında temel duygulardan başlanarak duygu yönetimi grup çalışmaları yapılabilir.

5. Veli seminerleri düzenlenerek IQ'nun yanında EQ'nun da bireyin yaşamındaki önemi konusunda bilinçlendirme çalışmaları yapılarak, duygu gelişimi ve yönetimi süreçlerine ilişkin bilgilendirmeler yapılmalıdır. 
6. Araştırmada, yalnızca katılımcıların verdikleri cevaplar dikkate alınarak sonuçlara ulaşılmıştır. Yaş grubu dikkate alındığında gelecekte yapılacak çalışmalar veli ve/veya öğretmen gözlemlerini de araştırma sürecine dahil edebilir.

\section{KAYNAKÇA}

Arbuckle, J. L. (2011). Amos (Version 23.0) [Computer Program]. Chicago: IBM SPSS.

Akar, C. (2008). Öz-Yeterlik İnancı ve İlkokuma Yazmaya Etkisi. Ușak Üniversitesi Sosyal Bilimler Dergisi, 1(2), 185-198.

Akçay, C. ve Çoruk, A. (2012). Çalışma Yaşamında Duygular ve Yönetimi: Kavramsal Bir İnceleme. Eğitimde Politika Analizi, 12 (1), 3-25.

Akın, A. Sarıçam, H., Akkuș, Z., Akın, Ü., Bilgin, O., \& Uğur, E. (2014). Çocuklar İçin Üzüntü Yönetimi Ölçeğinin Türkçeye uyarlanması: Geçerlik ve güvenirlik çalışması. 13. Sınıf Öğretmenliği Kongresi, 29-31 Mayıs, Kütahya

Akova, O. ve Işık, K. (2008). Otel İșletmelerinde Stres Yönetimi: İstanbul'daki Beş Yıldızlı Otel İşletmelerinde Bir Araştırma. Kocaeli Üniversitesi Sosyal Bilimler Enstitüsü Dergisi, 15(1), 17-44.

Alisinanoğlu, F. ve Ulutaș, İ. (2000). Çocuklarda Kaygı ve Bunu Etkileyen Etmenler. Çocuklarda Kaygı ve Bunu Etkileyen Faktörler. Milli Eğitim Dergisi, 145, 15-19.

Alisinanoğlu, F. ve Ulutaş, İ. (2003). Çocukların Kaygı Düzeyleri ile Annelerinin Kaygı Düzeyleri Arasındaki İlişkinin İncelenmesi. Eğitim ve Bilim, 28 (128), 65-71.

Alper, Y., Bayraktar, E. ve Karaçam, Ö. (2001). Herkes İçin Psikiyatri (1. baskı). İstanbul: Gendaş Kültür Yay.

Aral, N. ve Başar, F. (1998). Çocukların Kaygı Düzeylerinin Yaş, Cinsiyet, Sosyoekonomik Düzey ve Ailenin Parçalanma Durumuna göre İncelenmesi. Eğitim ve Bilim, 22, 110-120.

Arı, M. ve Yaban, H. (2016). Okulöncesi Dönemdeki Çocukların Sosyal Davranışları: Mizaç ve Duygu Düzenlemenin Rolü. Hacettepe Üniversitesi Eğitim Fakültesi Dergisi, 31 (1), 125-141. DOI:10.16986/HUJE.2015014655

Bandura, A. (1988). Self-efficacy conception of anxiety. Anxiety Research, 1 (2), 77-98. DOI:10.1080/10615808808248222

Bandura, A. (1990). Perceived self-efficacy in the exercise of control over aids infection. Evaluation and Program Planning, 13, 9-17.

Barutçugil, İ. (2004). Organizasyonlarda Duygu Yönetimi. İstanbul: Kariyer Yayınları.

Birkök, C. (2004). Poliste Çatış̧ma ve Stres Yönetimi. Uluslararası İnsan Bilimleri Dergisi, 1(1), 1-9.

Cenkseven, F. (2003). Öfke Yönetimi Becerileri Programının Ergenlerin Öfke ve Saldırganlık Düzeylerine Etkisi. Eğitim Bilimleri ve Uygulama, 2(4), 153-167

Çetin, B. (2013). Çocuklar için Öz-Yeterlik Ölçeğinin İlköğretim 4. ve 5.Sınıf Öğrencilerinin Akademik Başarısını Yordaması. Kastamonu Ĕgitim Dergisi, 21(3), 1117-1132.

Çetinkaya, Ö. ve Alparslan A.M. (2011). Duygusal Zekânın İletişim Becerileri Üzerine Etkisi: Üniversite Öğrencileri Üzerinde Bir Araştırma. Süleyman Demirel Üniversitesi İktisadi ve İdari Bilimler Fakültesi Dergisi, 16 (1), 363-377.

Dinçmen, K. (2004). Psikiyatri (1. baskı). İstanbul: Arion yay.

Geçtan, E. (1995). Psikodinamik Psikiyatri ve Normal Dışı Davranışlar. İstanbul: Remzi Kitabevi,11. Basım.

Güçlü, N. (2001). Stres yönetimi. Gazi Üniversitesi Gazi Eğitim Fakültesi Dergisi, 21(1), 91-109.

Güngör-Aytar, A., ve Kurbet-Dinçer, H. (2014). Investigation of emotional regulation skills preschoolers and emphatic tendency and attitude of mothers towards their children. Proceeding of IAC-SSaH. International Academic Conference on Social Sciences and Humanities, Czech Technical University in Prague, 282-292.

Holodynski, M. \& Friedlmeier, W. (2006). Development of emotions and emotion regulation. New York: Springer Science+Business Media, Inc.

Horney, K. (1998). Çağımızın Nevrotik Kişsiliği (3. baskı). Ankara: Öteki Psikoloji Dizisi

Hurrel, K.E., Hudson, J.L. \& Schniering, C.A. (2015). Parental reactions to children's negative emotions: Relationships with emotion regulation in children with an anxiety disorder. Journal of Anxiety Disorders, 29, 72-82.doi:10.1016/j.janxdis.2014.10.008

Johnson-Iaird, P.N. \& Oatley, K. (1989). The language of emotions: An analysis of semantic field. Cognition and Emotion, 3 (2), 81-123. doi:10.1080/02699938908408075

Karataş, Z. (2009). Bilişsel Davranışçı Teknikler Kullanılarak Yapılan Öfke Yönetimi Programının Ergenlerin Saldırganlığını Azaltmadaki Etkisi. Pamukkale Üniversitesi Eğitim Fakültesi Dergisi, 26, 12-24. 
Koçyiğit, S., Sezer, T. ve Yılmaz, E. (2015). 60-72 aylık çocukların sosyal yetkinlik ve duygu düzenleme becerileri ile oyun becerileri arasındaki ilişkinin incelenmesi. Hasan Ali Yücel Eğitim Fakültesi Dergisi, 12 (23), 209-218.

Korkmaz, M. (2005). Duyguların ve Liderlik Stillerinin Öğretmenlerin Performansı Üzerindeki Etkisi. Kuram ve Uygulamada Eğitim Yönetimi, 43, 401-422.

McKenzie, K. (2006). Anksiyete ve Panik Atak. İstanbul: Morpa Kültür yay.

Muris, P. (2001). A brief questionnaire for measuring self-efficacy in youths. Journal of Psychopathology and Behavioral Assessment, 23 (3), 145-149. Doi: 10.1023/A:1010961119608

Muris, P. (2002). Relationships between self-efficacy and symptoms of axiety disorders and depression in a normal adolescent sample. Personality and Individual Differences, 32(2), 337-348.

Önder, A. ve Gülay, H. (2007). Annelerin Kabul Red Düzeyi ile Çocuklarının Empati Becerisi Arasındaki İlişkinin İncelenmesi. Pamukkale Üniversitesi Eğitim Fakültesi Dergisi, 22 (2), 23-30.

Öner, N. ve Le Compte, A. (1985). Durumluk - Sürekli Kaygı Envanteri El Kitabı. İstanbul: Boğaziçi Üniversitesi Yayını.

Özbay, Y., Palancı, M., Kandemir, M. ve Çakır, O. (2012). Üniversite Öğrencilerinin Öznel İyi Oluşlarının Duygusal Düzenleme, Mizah, Sosyal Öz-Yeterlik ve Başa Çıkma Davranışları ile Yordanması. Türk Eğitim Bilimleri Dergisi, 10 (2), 325-345.

Plotnik, R. (2009). Psikolojiye Giriş (1. baskı). İstanbul: Kaknüs yay.

Sanders, W., Zeman, J. \& Poon, J. (2015). Child regulation of negative emotions and depressive symptoms: The moderating role of parental emotion socialization. Journal of Child and Family Studies, 24 (2), 402-415. Doi:10.1007/s10826-013-9850-y

Sarp, N. ve Tosun, A. (2011). Duygu ve otobiyografik bellek. Psikiyatride Güncel Yaklaşımlar, 3(3), 446-465.

Schunk, D.H. \& Meece, J.L. (2006). Self-efficacy development in adolescence. In F. Pajares \& T.C. Urdan (Eds.), Self-efficacy beliefs of adolescents (pp. 71-96). Connecticut: Information Age Pub.

Shipman, K., Edwards, A., Brown, A., Swisher, L. \& Jennings, E. (2005). Managing emotion in a maltreating context: A pilot study examining child neglect. Child Abuse \& Neglect, 29 (9), 1015-1029. doi:10.1016/j.chiabu.2005.01.006

Shipman, K.L. \& Zeman, J. (2001). Socialization of children's emotion regulation in mother-child dyads: A developmental psychopathology perspective. Development and Psychopathology,13(2), 317-336. Doi:10.1017/S0954579401002073

Soykan, Ç. (2003). Öfke ve Öfke Yönetimi. Kriz Dergisi,11(2), 19-27.

Spielberger, C.D., Gorsuch, R.C. \& Luschene, R.E. (1970). Manual for the State-Trait Anxiety Inventory. California: Consulting Psychologists Press.

Sroufe, L.A. (2000). Early relationships and the development of children. Infant Mental Health Journal, 21 (12), 67-74. Doi:10.1002/(SICI)1097-0355(200001/04)21:1/2<67::AID-IMHJ8>3.0.C0;2-2

Suveg, C. \& Zeman, J. (2004). Emotion regulation in children with anxiety disorders. Journal of Clinical Child and Adolescent Psychology, 33(4), 750-759. doi: 10.1207/s15374424jccp3304_10

Tashmassian, K. ve Moghadam, N.J. (2011). Relationship between self-efficacy and symptoms of aniety, depression, worry, and social avoidance in a normal sample of students. Iran Journal of Psychiatry Behavior Science, 5(2), 91-98.

Telef, B.B. ve Karaca, R. (2012). Çocuklar için Öz-Yeterlilik Ölçeği; Geçerlik ve Güvenirlik Çalışması. Buca Eğitim Fakültesi Dergisi, 32, 169-187.

Tillery, R., Cohen, R., Parra, G.R., Kitzmann, K.M. \& Howard-Sharp, K.M. (2015). Friendship and socialization of sadness. Merrill-Palmer Quarterly, 61(4), 486-508.

Töremen, F. ve Çankaya, İ. (2008). Yönetimde Etkili Bir Yaklaşım: Duygu Yönetimi. Kuramsal Eğitimbilim Dergisi, 1(1), 33-47.

Yerdelen, S., McCaffrey, A. \& Klassen, R.M. (2016). Longitudinal examination of procrastination and anxiety, and their relation to self-efficacy for self-regulated learning: Latent Growth Curve Modeling. Educational Sciences: Theory\&Practice, 16 (1), 5-22. DOI 10.12738/estp.2016.1.0108

Zeman, J., Shipman, K. \& Penza-Clyve, S. (2001). Development and initial validation of The Children's Sadness Management Scale. Journal of Nonverbal Behavior, 25 (3), 187-205. Doi: 10.1023/A:1010623226626

Zeman, J., Shipman, K. \& Suveg, C. (2002). Anger and sadness regulation: Predictions to internalizing and externalizing symptoms in children. Journal of Clinical Child \& Adolescent Psychology, 31 (3), 393-398. Doi: 10.1207/S15374424JCCP3103_11 